\title{
Posture, muscle endurance and ROM in individuals with and without neck pain
}

\author{
Postura, resistência muscular e ADM em \\ indivíduos com e sem dor cervical
}

Postura, resistencia muscular y ROM en
individuos con y sin dolor de cuello

Mateus Aimi ${ }^{\oplus}$, Emanuelle Francine Detogni Schmit ${ }^{\circledR}$, Rafael Paiva Ribeiro $₫$, Cláudia Tarragô Candotti ${ }^{*}{ }^{*}$

Universidade Federal do Rio Grande do Sul (UFRGS), Porto Alegre, RS, Brazil

\section{Abstract}

Introduction: Factors such as postural changes, reduced neck muscle endurance and reduced range of motion (ROM) are common characteristics attributed to people with neck pain. Objective: (a) Identify differences in postural, muscular endurance and ROM characteristics between individuals with and without neck pain and (b) relate the presence and intensity of neck pain with the characteristics of static posture, muscular endurance and cervical ROM. Method: A cross-sectional study with 60 subjects equally divided into two groups with respect to the presence of neck pain carrying out the following evaluations: (1) static postural evaluation by digital photogrammetry; (2) the neck flexor endurance test; and (3) evaluation of cervical ROM using a fleximeter. The data were analyzed with independent t-tests, the Mann-Whitney U test, and the Spearman and Tau of Kendall correlation tests $(\alpha<0.05)$. Results: There

\footnotetext{
* MA: BS, e-mail: mateus.aimi@gmail.com EFDS: Doctoral student, e-mail: manu_schmit@hotmail.com RPR: Master's student, e-mail: rpaivaribeiro2@gmail.com CTC: PhD, e-mail: claudia.candotti@ufrgs.br
} 
were no statistical differences between individuals with and without neck pain regarding the postural, muscle endurance and cervical ROM characteristics. No statistically significant correlations were found between pain and posture, muscle endurance and cervical ROM. Conclusion: Individuals with neck pain do not appear to present differences in their postural, neck flexor muscle endurance or cervical ROM characteristics when compared to individuals without neck pain, and neck pain appears to be unrelated to these variables.

Keywords: Neck Pain. Health Evaluation. Posture. Physical Resistance. Range of Motion. Articular.

\section{Resumo}

Introdução: Fatores como alterações posturais, redução da resistência muscular do pescoço e redução da amplitude de movimento (ADM) da cervical são características comuns atribuídas a pessoas com dor cervical. Objetivo: (a) Identificar diferenças existentes em relação às características posturais, de resistência muscular e de ADM entre indivíduos com e sem dor na região cervical e (b) relacionar a presença e intensidade da dor cervical com as características da postura estática, da resistência muscular e da ADM cervical. Método: Estudo transversal em que 60 indivíduos foram divididos igualmente em dois grupos quanto à presença de dor cervical. Foram realizados: (1) avaliação postural estática pela fotogrametria digital; (2) teste de resistência dos flexores do pescoço; e (3) avaliação da ADM cervical, por meio do flexímetro. Os dados foram analisados com: testes t independentes, U de Mann-Whitney, correlação de Spearman e Tau de Kendall $(\alpha<0,05)$. Resultados: Não houve diferença estatística quanto às características posturais, de resistência muscular e de ADM da cervical entre os indivíduos com e sem dor cervical. Não foram encontradas correlações estatisticamente significativas entre a dor e a postura, a resistência muscular e a ADM da cervical. Conclusão: Indivíduos com dor cervical parecem não apresentar diferenças relacionadas às características posturais, de resistência muscular do flexores do pescoço e de ADM da cervical quando comparados a indivíduos sem dor cervical, bem como a dor cervical parece não ter relação com essas variáveis.

Palavras-chave: Cervicalgia. Avaliação em Saúde. Postura. Resistência Física. Amplitude de Movimento Articular.

\section{Resumen}

Introducción: Factores como los cambios posturales, la reducción de la resistencia del músculo del cuello y la reducción del rango de movimiento (RDM) son características comunes atribuidas a las personas con dolor de cuello. Objetivo: Verificar si existen: (a) diferencias en las características posturales, resistencia muscular y RDM entre individuos con y sin dolor en la región cervical y (b) relación entre la presencia e intensidad del dolor de cuello con las características de la postura estática, resistencia muscular y ROM cervical. Método: Estudio Transversal cuyos 60 sujetos se dividieron por igual en dos grupos con respecto a la presencia de dolor en el cuello. Se realizó: (1) evaluación postural estática, mediante fotogrametría digital; (2) la prueba de resistencia de los flexores del cuello; y (3) evaluación de la RDM cervical usando el flexímetro. Los datos se analizaron con: pruebas $t$ independientes, $U$ de Mann-Whitney, correlación de Spearman y Tau de Kendall $(\alpha<0,05)$. Resultados: No hubo diferencias estadísticas con respecto a la postural, la resistencia muscular y las características de la RDM cervical entre las personas con y sin dolor de cuello. No se encontraron correlaciones estadísticamente significativas entre el dolor y la postura, la resistencia muscular y la RDM del cuello. Conclusión: Las personas con dolor de cuello no parecen presentar diferencias en las características posturales, la resistencia muscular de los flexores del cuello y la RDM cervical en comparación con las personas sin dolor de cuello, y el dolor de cuello parece no estar relacionado con estas variables.

Palabras clave: Dolor del Cuello. Evaluácion en Salud. Postura. Resistencia Física. Rango del Movimiento Articular. 


\section{Introduction}

Neck pain is a very common problem increasing in the world population [1]. According to data from "Global Burden of Disease Study - 2016", neck pain, together with back pain, was in 2015 the main cause of incapacity in the majority of countries [2]. In Brazil, back and neck pains are in the first place in the ranking of health problems that most cause incapacity, with an increase of $22.8 \%$ in the 2005 2006 period [3].

Being a musculoskeletal pain, a sore neck is an extremely complex problem and has multifactorial character [4]. Three recent systematic reviews have indicated some factors as being at risk for the development of neck pain, amongst which: smoking, obesity, being downcast, role conflict, high work demands, and a previous history of neck or back pains $[4,5,6]$. Various studies have associated several other factors with the appearance of neck pain, such as, for example, an increase in the use of computers [7], stress and psychological suffering [8-10]; and physical factors such as a reduction in muscle endurance [11, 12] and postural alterations [13-15]. In addition, a reduction in the range of cervical movement (ROM) is one of the main complaints of individuals with neck pain [16].

Regarding the role of posture in the development of neck pain, there is no consensus in the literature. In a systematic review, Silva et al. [17] affirmed there was insufficient evidence to determine alterations in the head position differed between individuals with and without neck pain. On the other hand, Lau et al. [15] suggested that individuals with this type of pain showed alterations when inclining the head to the front and an increase in thoracic kyphosis, in comparison to asymptomatic individuals. With respect to the association between muscle endurance [18-20] and ROM [21-24] with neck pain, the literature also presents controversial results.

The knowledge of possible postural, muscle endurance and ROM differences between individuals with and without neck pain, and also the relationship between these variables, could help to establish strategies for the adequate treatment and prevention. Thus, the objectives of this study were: (a) to identify any differences between individuals with and without neck pain concerning postural characteristics, muscle endurance and ROM, and (b) relate the presence and intensity of neck pain with the characteristics of static posture, muscle endurance and ROM of the cervical spine.

\section{Methods}

This cross-sectional study [25] was approved by the Ethics Committee in the Research Commission of the University where it was carried out (CAAE: 55897216.6.0000.5347), being in line with the guidelines of resolution 466/12 of the Brazilian National Health Council.

The sample size was calculated using the t-test family (difference between two independent groups) for a bicaudal test using the $\mathrm{G}^{*}$ Power 3.1 .7 software, assuming large-size effects (0.8) for all the variables, an alpha of 0.05 and a power of $80 \%$, requiring 52 individuals. Thus, considering possible sample losses, 60 individuals of both sexes were invited to take part, all participants of the University Extension Project.

The inclusion criteria consisted of manifesting interest in taking part in the study and being in the age range between 18 and 60 . The exclusion criteria were having been submitted to any surgical intervention of the spine and suffering from any acute musculoskeletal pain which would make it difficult to carry out the tests of the evaluation protocol.

The sample was recruited in a consecutive way between May 2016 and August 2017, and the individuals evaluated in the same week they were recruited. To carry out the anamnesis and select the individuals, two questions from the self-administered questionnaire 'Back pain and body posture evaluation instrument for adults' (BackPEI-A), valid and reproducible [26], were used. Question 17 assessed the presence of neck pain in the last three months and question 20 evaluated the intensity of the neck pain on a visual analogical scale (VAS). The individuals allocated in the neck pain group (NPG) responded in a positive way to the presence of neck pain, whereas the individuals who responded negatively to question 17 were allocated in the neck pain free group (NPFG).

All the evaluations were carried out by a previously trained team. The team was trained for $20 \mathrm{~h}$ to learn how to use all the instruments and apply the evaluation protocol. Each individual was evaluated by an examiner on the same day and location. The evaluation protocol consisted of: (1) evaluation of the static posture by digital photogrammetry based on the protocol of the 'Digital Image-based Postural Assessment' software 
$\left(\right.$ DIPA $\left.^{\odot}\right)[27,28]$; (2) determination of the neck flexor muscle endurance by the neck flexor muscle endurance test [29]; and (3) determination of the ROM of the cervical spine using a fleximeter [30]. The validity and reproducibility of the DIPA ${ }^{\odot}$ software protocol, the Fleximeter and the muscle endurance test have been duly confirmed [21, 27, 28, 31, 32]. The results of the evaluations were analyzed by a researcher who did not take part in the evaluations, thus avoiding evaluation bias.

\section{Evaluation of static posture}

The photographic records based on the DIPA ${ }^{\odot}$ protocol $[27,28]$ were obtained using a digital camera (Sony Cyber-Shot Dsc-w510 12.1 megapixels) fixed to a tripod $95 \mathrm{~cm}$ above the ground at a horizontal distance of $280 \mathrm{~cm}$ from the subjects under evaluation. Two reflexive markers fixed to a plumb line, at a distance of $100 \mathrm{~cm}$ one from the other, were used as the vertical reference, and the horizontal reference was assumed to be perpendicular to the plumb line. The anatomical points of interest were identified by reflexive markers before acquiring the images, including: the right tragus and spiny processes of the first (C1) and seventh (C7) cervical vertebrae and the second (T2) and twelfth (T12) thoracic vertebrae. The individuals, dressed in swimwear, were instructed to lie down and remain in the sagittal plane in the right profile position, in a way that the right malleolus was the same distance from the camera as the plumb line.

The photos were then analyzed by the DIPA ${ }^{\odot}$ software, which provides information about the individual's posture. The head position variables (defined as the angle formed between the right tragus, C7 and a horizontal line parallel to the ground that intercepted the $\mathrm{C} 7$ point; a neutral head position being, considered between $50^{\circ}$ and $60^{\circ}$, back-inclined $>60^{\circ}$ and forward-inclined $<50^{\circ}$ ) [33] and of the curvature angles of the cervical spine (formed between $\mathrm{C} 1$ and C7; considered as physiological cervical lordosis between $35^{\circ}$ and $45^{\circ}$, increased $>45^{\circ}$ and decreased $<35^{\circ}$ ), and of the thoracis spine (formed between T2 and T12; considered as physiological dorsal kyphosis between $32.4^{\circ}$ and $47.4^{\circ}$, increased $>47.4$ and decreased $<32.4^{\circ}$ ) [34].
Evaluation of muscle endurance

The neck flexor endurance test [29] was used to measure the endurance of the neck flexor musculature. The individual was placed lying down on a stretcher with his arms beside his body. He was then instructed to flex his neck so as to raise the head about $2.5 \mathrm{~cm}$ from the stretcher and maintain this position for 35 seconds, one of the evaluator's hands being held under the individual's head. The test ended on completing the 35 seconds in this position without compensation, when he let his head fall into the evaluator's hand, or on losing the neck flexion. To interpret the analysis, the individuals were classified into two categories: 1) "managed to execute" - managed to remain in the position with the head $2.5 \mathrm{~cm}$ from the stretcher for at least 35 seconds with good neck flexion; and 2) "did not manage to execute" - failed to remain in the position for at least 35 seconds.

\section{ROM evaluation}

To evaluate the ROM of cervical flexion and extension, the individual seated on a chair with a Fleximeter (Sanny ${ }^{\circledR}$ - Brazil) fixed to the side of his/her head with elastic bands [30]. The lateral inclination ROM was assessed with the Fleximeter positioned to the back of the cranium on the occiput. To evaluate cervical rotation the individuals were placed in the supine position on a stretcher, with the instrument fixed to the top of the head and the elastic bands passing under the jaw. For each movement the device was zeroed in the neutral position and the individual then instructed to carry out the flexion; extension; lateral inclinations to the right and left; and cervical rotation to the right and left, respectively [35]. The maximum angles reached for each movement, without compensation as observed by the evaluators, represented the ROM recorded. The following values were considered normal: $61-93^{\circ}$ for flexion, $48-69^{\circ}$ for extension, 38-49 for inclination and $70-92^{\circ}$ for rotation [36].

\section{Statistical analysis}

The statistical treatment was carried out using the software SPSS v. 20.0 by descriptive (percentage, 
mean and standard deviation) and inferential statistics, adopting $\alpha=0.05$. The normality of the data was verified by the Kolmogorov-Smirnov test. The independent $t$-test was applied for the variables with a normal distribution and the Mann-Whitney U test for the variables with a non-normal distribution and for those with a categorical nature to compare one with the other. On the other hand, the Spearman and Tau of Kendall correlation tests were applied to make the correlations, adopting the Hopkins classification [37] for their interpretation, categorized as very low $(r<0.1)$, low (between 0.1 and 0.3 ), moderate (between 0.3 and 0.5), high (between 0.5 and 0.7), very high ( 0.7 to 0.9 ) and almost perfect (between 0.9 and 1). All the analyses were carried out according to Field [38].

\section{Results}

Sixty individuals were evaluated $(61.7 \%$ women; $38.3 \%$ men; age: $32.4 \pm 13.3$ years; body mass: $70.6 \pm 13.5 \mathrm{~kg}$; height: $164.6 \pm 23.6 \mathrm{~cm}$ ), divided equally into two groups, with and without neck pain. The two groups did not differ with respect to their demographic characteristics (Gender: $\mathrm{U}=435.0 ; \mathrm{z}=-0.263$; $\mathrm{p}=1.000$; age: $\mathrm{U}=414.5 ; \mathrm{z}=-0.526 ; \mathrm{p}=0.604$; body mass: $\mathrm{U}=409.5 ; \mathrm{z}=-0.599 ; \mathrm{p}=0.554$; height: $\mathrm{U}=420.5$; $\mathrm{z}=-0.436 ; \mathrm{p}=0.667$ ) (Table 1). Concerning pain intensity, the mean value for the individuals in the group with neck pain was $4.5 \pm 2.2 \mathrm{~cm}$ on the VAS scale.

Table 1 - Demographic characterization of the sample stratified according to neck pain

\begin{tabular}{lcc}
\hline Variables & $\begin{array}{c}\text { With neck pain } \\
(\mathbf{n}=\mathbf{3 0})\end{array}$ & $\begin{array}{c}\text { Without neck pain } \\
(\mathbf{n}=\mathbf{3 0})\end{array}$ \\
\hline Gender & & \\
Men $(\%)$ & 40 & 36.7 \\
Women (\%) & 60 & 63.3 \\
Age (years) & $32.3 \pm 11.9$ & $32.6 \pm 14.8$ \\
Body mass $(\mathrm{kg})$ & $69.6 \pm 15.2$ & $71.6 \pm 11.9$ \\
Height $(\mathrm{cm})$ & $161.8 \pm 32.1$ & $167.5 \pm 9.4$ \\
\hline
\end{tabular}

The postural, muscle endurance and cervical ROM characteristics also did not differ between the individuals with and without neck pain (Table 2).

Table 2 - Comparison of the variables related to posture, muscle endurance and cervical ROM between individuals with and without neck pain

\begin{tabular}{|c|c|c|c|c|}
\hline Variables & & $\begin{array}{l}\text { With neck pain } \\
\quad(\mathrm{n}=30)\end{array}$ & $\begin{array}{l}\text { Without neck pain } \\
\qquad(\mathrm{n}=30)\end{array}$ & Statistics (t; p; Cl 95\%) \\
\hline \multirow{3}{*}{ Static posture } & Head position $\left({ }^{\circ}\right)$ & $51.9 \pm 4.9$ & $53.2 \pm 4.5$ & $\mathrm{t}(58)=1.097 ; p=0.277 ; \mathrm{Cl}=-3.767-1.100$ \\
\hline & Cervical Iordosis $\left(^{\circ}\right)$ & $44.9 \pm 13.4$ & $47.7 \pm 12.9$ & $t(58)=0.816 ; p=0.418 ; C l=-9.551-4.018$ \\
\hline & Thoracic kyphosis $\left(^{\circ}\right)$ & $37.9 \pm 8.0$ & $39.3 \pm 11.6$ & $\mathrm{t}(58)=0.544 ; \mathrm{p}=0.589 ; \mathrm{Cl}=-6.555-3.755$ \\
\hline $\begin{array}{l}\text { Muscle } \\
\text { endurance }\end{array}$ & $\begin{array}{l}\text { Endurance of neck flexors } \\
\text { (\% that manage to execute) }\end{array}$ & 96.7 & 90 & $U=420.0 ; z=-1.026 ; p=0.612$ \\
\hline \multirow{8}{*}{ ROM } & Cervical flexion $\left(^{\circ}\right)$ & $59.2 \pm 10.2$ & $59.3 \pm 10.8$ & $t(58)=0.037 ; p=0.971 ; C l=-5.528-5.328$ \\
\hline & Cervical extension $\left({ }^{\circ}\right)$ & $70.4 \pm 13.0$ & $68.9 \pm 14.8$ & $t(58)=-0.425 ; p=0.672 ; C l=-5.683-8.750$ \\
\hline & Inclination $\left({ }^{\circ}\right)$ & & & \\
\hline & To the right & $44.7 \pm 9.3$ & $46.9 \pm 11.3$ & $t(58)=0.846 ; p=0.401 ; C l=-7.632-3.100$ \\
\hline & To the left & $46.6 \pm 10.6$ & $46.0 \pm 8.9$ & $\mathrm{t}(58)=-0.250 ; \mathrm{p}=0.804 ; \mathrm{Cl}=-4.441-5.707$ \\
\hline & Rotation $\left({ }^{\circ}\right)$ & & & \\
\hline & To the right & $69.8 \pm 10.8$ & $69.0 \pm 12.2$ & $\mathrm{t}(58)=-0.262 ; \mathrm{p}=0.794 ; \mathrm{Cl}=-5.195-6.761$ \\
\hline & To the left & $72.2 \pm 10.0$ & $70.7 \pm 8.8$ & $t(58)=-0.616 ; p=0.540 ; C l=-3.370-6.370$ \\
\hline
\end{tabular}

Note: Symbols: $\mathrm{t}=$ independent $\mathrm{t}$-test; $\mathrm{U}=$ Mann-Whitney test.

It should also be mentioned that no statistically significant correlations were found between the variables related to presence and intensity of pain, and the postural variables, of muscle endurance and cervical ROM (Table 3). 
Table 3 - Correlations between the variables of the presence and intensity of pain and the variables related to posture, muscle endurance and cervical ROM

\begin{tabular}{|c|c|c|c|}
\hline & Variables & Presence of neck pain $(n=30)$ & Intensity of neck pain $(n=30)$ \\
\hline \multirow{3}{*}{ Static posture } & Head position & $r_{\mathrm{s}}=-0.114, \mathrm{p}=0.386$ & $r_{\mathrm{s}}=0.225, \mathrm{p}=0.231$ \\
\hline & Cervical lordosis & $r_{s}=-0.092, p=0.487$ & $r_{\mathrm{s}}=0.027, p=0.889$ \\
\hline & Thoracic kyphosis & $r_{\mathrm{s}}=-0.071, \mathrm{p}=0.588$ & $r_{\mathrm{s}}=-0.202, \mathrm{p}=0.285$ \\
\hline Muscle endurance & Neck flexor endurance & $\tau=0.134, p=0.309$ & $r_{\mathrm{s}}=0.250, \mathrm{p}=0.182$ \\
\hline \multirow{8}{*}{ ROM } & Neck flexion & $r_{\mathrm{s}}=0.005, \mathrm{p}=0.971$ & $r_{\mathrm{s}}=0.045, \mathrm{p}=0.814$ \\
\hline & Neck extension & $r_{\mathrm{s}}=0.065, \mathrm{p}=0.624$ & $r_{\mathrm{s}}=-0.011, p=0.954$ \\
\hline & Inclination & & \\
\hline & Right & $r_{\mathrm{s}}=-0.100, p=0.445$ & $r_{\mathrm{s}}=0.059, \mathrm{p}=0.756$ \\
\hline & Left & $r_{s}=0.062, p=0.639$ & $r_{s}=-0.156, p=0.410$ \\
\hline & Rotation & & \\
\hline & Right & $r_{s}=0.058, p=0.660$ & $r_{\mathrm{s}}=-0.173, \mathrm{p}=0.360$ \\
\hline & Left & $r_{\mathrm{s}}=0.093, \mathrm{p}=0.480$ & $r_{s}=-0.053, p=0.781$ \\
\hline
\end{tabular}

Note: Symbols: $r_{s}=$ Spearman's correlation test; $\tau=$ Tau of Kendall's correlation test.

\section{Discussion}

The initial hypothesis of this study was that individuals with neck pain would present some type of difference in posture, in the muscle endurance or ROM when compared with individuals without neck pain. An additional hypothesis was that there would be a relationship between neck pain and these same variables. These hypotheses were not confirmed. Nevertheless, Lee et al. [11], Falla et al. [39] and Lomas-Vega et al. [40], in studies analyzing the effect of postural interventions, and also Oliveira and Silva [12] and Piva et al. [23] in cross-sectional studies, on analyzing muscle endurance in adolescents and ROM as related to incapacity in adults, respectively, found differences between individuals with and without pain.

In summary, the results demonstrate that individuals with and without neck pain do not present statistically significant differences concerning static postural characteristics in the sagittal plane, neck flexor muscle endurance or cervical ROM. In addition, no significant correlations were found between the presence and intensity of the pain and the variables studied, i.e., "more pain" does not mean "more alteration".

Grob et al. [41] studied the relationship between the presence of neck pain and alterations in cervical kyphosis. The authors, as in our study, divided the individuals into two groups according to the presence of neck pain or not. Their results corroborate the results of our research, since the authors failed to find significant differences between the groups in relation to the sagittal curvature of the cervical spine, and concluded the alterations in cervical lordosis in individuals with pain should be considered a coincidence, that is, not necessarily indicative of the cause of the pain.

Also in consonance with these results, McFarland et al. [42] studied two methods to evaluate the sagittal alignment of the cervical spine in a sample of symptomatic and asymptomatic individuals, and again found no significant differences between the groups. Concerning head position, Silva et al. [43] observed that individuals with neck pain had a posture with the head in a more forward position than individuals with no pain. However, the mean difference between the groups was only $3.2^{\circ}$, making the clinical significance of this finding questionable. In the study described here the group of individuals with pain also showed a posture with the head position on average more to the front, but the difference was only $1.3^{\circ}$ in relation to the asymptomatic group, and, differently from Silva et al. [43], the result was not statistically significant.

The forward position of the head could be related to a weakness of the deep flexor cervical musculature [44]. Since, in this study, the groups with and without neck pain presented very similar values for the variable of head position, it is reasonable that there would not be much difference between the groups for the result of the neck flexor muscle endurance test. However, Oliveira and Silva [12] found a more forward head position for the asymptomatic group, 
and at the same time, better results for the neck flexor muscle endurance test. These findings demonstrate the lack of clarity in the relationship between pain and postural alterations and between postural alterations and muscle endurance, showing the need for more studies.

With respect to ROM, the means for both groups were similar and the results indicated that the individuals were within the normality standards, with a discrepancy of less than $2^{\circ}$ from the range of normality for more (extension) and for less (flexion and rotation) (Table 2) [36]. The association between ROM and neck pain was studied by Howell [45], who carried out a literature review from which he concluded that despite the fact that the ROM provided important data concerning neck function, expressive results were not found for the relationship between ROM and neck pain. For example, Ylinen et al. [22] verified the relation between neck pain and ROM in 179 women and found no statistically significant correlation between neck pain, the perception of incapacity and ROM.

The results of our study go against the common clinical and social belief that neck pain is intimately related to physical and postural alterations. The findings revealed that individuals without pain presented the same postural, muscle endurance and ROM characteristics as individuals with pain. These results possibly raise the idea that neck pain is associated with changes in the regulatory mechanisms of pain and not in biomechanical mechanisms, and hence neck pain should be considered a biopsychosocial aspect [46], related to symptoms such as psychological suffering, selfperception of the health and a previous history of pain [9]. In addition, three recent systematic reviews made it evident that biomechanical aspects were not included as important risk factors for neck pain, instead of which psychosocial aspects such as smoking, high work demands and inadequate social support were included [4-6].

The following also stand out as limitations of the study here described: the non-matching of the sample; the fact that only neck pain in the last three months was investigated, which could have included individuals with different characteristics and pain cases; and the analysis only of biomechanical factors. For future surveys the authors suggest tools that evaluate the presence of psychosocial factors, such as SF-36 [1] and Brief Pain Inventory Short Form [47] questionnaires. Considering the above, it is plausible to infer that the literature still lacks scientific evidence to establish if biomechanical factors related to the development of neck pain do indeed exist, and if they do, which ones and what is their true importance.

\section{Conclusion}

According to the sample studied, the individuals with neck pain presented no differences regarding postural, neck flexor muscle endurance or cervical ROM characteristics, when compared to individuals without neck pain, and nor did neck pain have any relationship with these variables, suggesting that biomechanical aspects are not at the center of neck pain casuistry.

\section{References}

1. Blanpied PR, Gross AR, Elliott JM, Devaney LL, Clewley D, Walton DM, et al. Neck pain: revision 2017: clinical practice guidelines linked to the international classification of functioning, disability and health from the orthopaedic section of the American Physical Therapy Association. J Orthop Sports Phys Ther. 2017;47(7):A1-83.

2. Vos T, Allen C, Arora M, Barber RM, Bhutta ZA, Brown $A$, et al. Global, regional, and national incidence, prevalence, and years lived with disability for 310 diseases and injuries, 1990-2015: a systematic analysis for the Global Burden of Disease Study 2015. Lancet. 2016;388(10053):1545-602.

3. Institute for Health Metrics and Evaluation. Brazil. Seatle: IHME; 2017 [cited 2017 Dec 4]. Available from: http://www.healthdata.org/brazil.

4. Paksaichol A, Lawsirirat C, Janwantanakul P. Contribution of biopsychosocial risk factors to nonspecific neck pain in office workers: a path analysis model. J Occup Health. 2015;57(2):100-9.

5. McLean SM, May S, Klaber-Moffett J, Sharp DM, Gardiner E. Risk factors for the onset of nonspecific neck pain: a systematic review. J Epidemiol Community Health. 2010;64(7):565-72. 
6. Kim R, Wiest C, Clark K, Cook C, Horn M. Identifying risk factors for first-episode neck pain: a systematic review. Musculoskeletal Sci Pract. 2018;33:77-83.

7. Straker LM, Smith AJ, Bear N, O'Sullivan PB, de Klerk NH. Neck/shoulder pain, habitual spinal posture and computer use in adolescents: the importance of gender. Ergonomics. 2011;54(6):539-46.

8. Paksaichol A, Janwantanakul P, Purepong N, Pensri $\mathrm{P}$, van der Beek AJ. Office workers' risk factors for the development of non-specific neck pain: a systematic review of prospective cohort studies. Occup Environ Med. 2012;69(9):610-8

9. Croft PR, Lewis M, Papageorgiou AC, Thomas E, Jayson MI, Macfarlane GJ, et al. Risk factors for neck pain: a longitudinal study in the general population. Pain. 2001;93(3):317-25.

10. Walker-Bone K, Palmer KT, Reading I, Coggon D, Cooper C. Prevalence and impact of musculoskeletal disorders of the upper limb in the general population. Arthritis Rheum. 2004;51(4):642-51.

11. Lee H, Nicholson LL, Adams RD. Neck muscle endurance, self-report, and range of motion data from subjects with treated and untreated neck pain. J Manipulative Physiol Ther. $2005 ; 28(1): 25-32$.

12. Oliveira AC, Silva AG. Neck muscle endurance and head posture: a comparison between adolescents with and without neck pain. Man Ther. 2016;22:62-7.

13. Osmotherly $\mathrm{P}$, Attia J. The interplay of static and dynamic postural factors in neck pain. Hong Kong Physiother J. 2008;26(1):9-17.

14. Yip $\mathrm{CH}$, Chiu TT, Poon AT. The relationship between head posture and severity and disability of patients with neck pain. Man Ther. 2008;13(2):148-54.

15. Lau KT, Cheung KY, Chan MH, Lo KY, Chiu TT. Relationships between sagittal postures of thoracic and cervical spine, presence of neck pain, neck pain severity and disability. Man Ther. 2010;15(5):457-62.
16. Audette I, Dumas JP, Côté JN, De Serres SJ. Validity and between-day reliability of the cervical range of motion (CROM) device. J Orthop Sports Phys Ther. 2010;40(5):318-23.

17. Silva AG, Sharples P, Johnson MI. Studies comparing surrogate measures for head posture in individuals with and without neck pain. Phys Ther Rev. 2010;15(1):12-22.

18. Chiu TT, Lo SK. Evaluation of cervical range of motion and isometric neck muscle strength: reliability and validity. Clin Rehabil. 2002;16(8):851-8.

19. Ylinen JJ, Savolainen S, Airaksinen O, Kautiainen H, Salo P, Häkkinen A. Decreased strength and mobility in patients after anterior cervical diskectomy compared with healthy subjects. Arch Phys Med Rehabil. 2003;84(7):1043-7.

20. Grimmer K, Trott P. The association between cervical excursion angles and cervical short flexor muscle endurance. Aust J Physiother. 1998;44(3):201-7.

21. Kumbhare DA, Balsor B, Parkinson WL, Bsckin PH, Bedard M, Papaioannou A, et al. Measurement of cervical flexor endurance following whiplash. Disabil Rehabil. 2005;27(14):801-7.

22. Ylinen J, Takala E-P, Kautianinen H, Nykanen M, Hakkinen A, Pohjolainen T, et al. Association of neck pain, disability and neck pain during maximal effort with neck muscle strength and range of movement in women with chronic non-specific neck pain. Eur J Pain. 2004;8(5):473-8.

23. Piva SR, Erhard RE, Childs JD, Browder DA. Intertested reliability of passive intervertebral and active movements of the cervical spine. Man Ther. 2006;11(4):321-30.

24. Jordan A, Mehlsen J, Ostergaard K. A comparison of physical characteristics between patients seeking treatment for neck pain and age-matched healthy people. J Manipulative Physiol Ther. 1997;20(7):468-75.

25. Pereira, MG. Epidemiologia: teoria e prática. Rio de Janeiro: Guanabara Koogan; 2015. 
26. Candotti CT, Delogni Schmit EF, Pivotto LR, Raupp EG, Noll M, Vieira A, et al. Back pain and body posture evaluation instrument for adults: expansion and reproducibility. Pain Manag Nurs. 2018;19(4):415-23.

27. Furlanetto TS, Chaise FO, Candotti CT, Loss JF. Fidedignidade de um protocolo de avaliação postural. J Phys Educ. 2011;22(3):411-9.

28. Furlanetto TS, Candotti CT, Sedrez JA, Noll M, Loss JF. Evaluation of the precision and accuracy of the DIPA software postural assessment protocol. Eur J Physiother. 2017;19(4):179-84.

29. Harris KD, Heer DM, Roy TC, Santos DM, Whitman JM, Wainner RS. Reliability of a measurement of neck flexor muscle endurance. Phys Ther. 2005;85(12):1349-55.

30. Achour A Jr, Nascimento MA, Franco R, Silva VP, Martins VF, Guariglia DA. Comparison of methods for assessing cervical range of motion in college men. J Phys Educ. 2013;24(4):609-16.

31. de Koning CH, van den Heuvel SP, Staal JB, SmitsEngelsman BC, Hendriks EJ. Clinimetric evaluation of methods to measure muscle functioning in patients with non-specific neck pain: a systematic review. BMC Musculoskeletal Disord. 2008;9:142.

32. Hole, DE, Cook, JM, Bolton, JE. Reliability and concurrent validity of two instruments for measuring cervical range of motion: effects of age and gender. Man Ther. 1995;1(1),36-42.

33. Raine S, Twomey L. Posture of the head, shoulders and thoracic spine in comfortable erect standing. Aust J Physiother. 1994;40(1):25-32.

34. Oliveira TS, Candotti CT, La Torre M, Pelinson PP, Furlanetto TS, Kutchak FM, et al. Validity and reproducibility of the measurements obtained using the flexicurve instrument to evaluate the angles of thoracic and lumbar curvatures of the spine in the sagittal plane. Rehabil Res Pract. 2012;2012:186156.

35. Cleland JA, Childs JD, Fritz JM, Whitman JM. Interrater reliability of the history and physical examination in patients with mechanical neck pain. Arch Phys Med Rehabil. 2006;87(10):1388-95.
36. Chen J, Solinger AB, Poncet JF, Lantz CA. Metaanalysis of normative cervical motion. Spine. 1999;24(15):1571-8.

37. Hopkins WG. A new view of statistics. Internet Society for Sport Science; 2000 [cited 2019 Jan 31]. Available from: http://www.sportsci.org/resource/ stats/.

38. Field A. Discovering statistics using SPSS: introducing statistical method. 3th ed. London: Sage; 2009.

39. Falla D, Jull G, Russell T, Vicenzino B, Hodges P. Effect of neck exercise on sitting posture in patients with chronic neck pain. Phys Ther. 2007;87(4):408-17.

40. Lomas-Vega R, Garrido-Jaut MV, Rus A, del-PinoCasado R. Effectiveness of global postural reeducation for treatment of spinal disorders: a metaanalysis. Am J Phys Med Rehabil. 2017;96(2):124-30.

41. Grob D, Frauenfelder H, Mannion AF. The association between cervical spine curvature and neck pain. Eur Spine J. 2007;16(5):669-78.

42. McFarland C, Wang-Price S, Richard S. Clinical measurements of cervical lordosis using flexirule and inclinometer methods in individuals with and without cervical spine dysfunction: a reliability and validity study. J Back Musculoskelet Rehabil. 2015;28(2):295-302.

43. Silva AG, Punt TD, Sharples P, Vilas-Boas JP, Johnson MI. Head posture and neck pain of chronic nontraumatic origin: a comparison between patients and pain-free persons. Arch Phys Med Rehabil. 2009;90(4):669-74.

44. Ishida H, Suehiro T, Kurozumi C, Ono K, Ando $\mathrm{S}$, Watanabe S. Correlation between neck slope angle and deep cervical flexor muscle thickness in healthy participants. J Bodyw Mov Ther. 2015;19(4):717-21.

45. Howell ER. The association between neck pain, the Neck Disability Index and cervical ranges of motion: a narrative review. J Can Chiropr Assoc. 2011;55(3):211-21. 
46. Richards KV, Beales DJ, Smith AJ, O'Sullivan PB, Straker LM. Neck posture clusters and their association with biopsychosocial factors and neck pain in Australian adolescents. Phys Ther. 2016;96(10):1576-87.

47. Turk DC, Fillingim RB, Ohrbach R, Patel KV. Assessment of psychosocial and functional impact of chronic pain. J Pain. 2016;17(9 Suppl):T21-49.
Received on 05/22/2018

Recebido em 22/05/2018

Recibido en 22/05/2018

Approved on 01/16/2019

Aprovado em 16/01/2019

Aprobado en 16/01/2019 